\title{
HUBUNGAN STATUS KEBUGARAN JASMANI DAN STATUS GIZI DENGAN PRODUKTIVITAS KERJA PEKERJA PEMBUAT BUIS BETON
}

\author{
Oleh: Hari Wahyono dan Prijo Sudibjo \\ Pendidikan Kesehatan dan Rekreasi FIK - UNY
}

\begin{abstract}
Abstrak
Penelitian ini bertujuan untuk mengetahui hubungan status kebugaran jasmani dan status gizi dengan produktivitas kerja pekerja pembuat buis beton di Dusun Blawong I, Trimulyo, Jetis, Bantul. Desain yang digunakan dalam penelitian ini adalah penelitian observasi cross sectional.

Populasi dalam penelitian ini adalah seluruh pekerja pembuat buis beton di Dusun Blawong I, Trimulyo, Jetis, Bantul. Sampel dalam penelitian ini berjumlah lima belas orang yang diperoleh dengan menggunakan teknik purposive sampling. Teknik analisis data menggunakan uji korelasi product moment dan uji regresi $(\alpha=0,05)$.

Hasil uji korelasi menunjukkan bahwa terdapat hubungan yang signifikan antara daya tahan jantung-paru danproduktivitas kerja $(\mathrm{p}=0,005)$ dan $(\mathrm{r}=0,743)$, kekuatan otot tungkai dengan produktivitas kerja $(\mathrm{p}=0,030)$ dan $(\mathrm{r}=0,559)$, kekuatan otot lengan dengan produktivitas kerja $(\mathrm{p}=0,002)$ dan $(\mathrm{r}=0,729)$, kelentukan dengan produktivitas kerja $(p=0,009)$ dan $(r=0,647)$, persentase lemak dengan produktivitas kerja $(p=0,033)$ dan $(\mathrm{r}=-0,551)$. Terdapat hubungan yang signifikan antara status gizi dan produktivitas kerja $(\mathrm{p}=0,040)$ dan $(\mathrm{r}=0,536)$. Hasil uji regresi menunjukkan terdapat hubungan yang signifikan antara status kebugaran jasmani dan status gizi dengan produktivitas kerja $(\mathrm{p}=$ 0,004).
\end{abstract}

Kata Kunci: status kebugaran jasmani, status gizi, dan produktivitas kerja

Produktivitas kerja setiap orang berbeda, salah satunya bergantung pada ketersediaan zat gizi dalam tubuh. Konsumsi makanan tiap hari merupakan dasar yang menentukan keadaan gizi seseorang. Pekerja yang mempunyai asupan gizi baik akan berpengaruh pada kondisi tubuhnya sehingga produktivitas kerja juga akan jadi lebih baik. Gizi kerja merupakan salah satu syarat untuk mencapai derajat kesehatan yang optimal, khususnya bagi masyarakat pekerja (Sri Rahayu, 2012: 75). Salah satu upaya yang mempunyai dampak cukup penting dalam meningkatkan sumber daya manusia adalah peningkatan status gizi. Status gizi yang baik juga akan memengaruhi produktivitas kerja sesorang. Peningkatan status gizi diarahkan pada peningkatan intelektualitas, produktivitas kerja, prestasi belajar, dan prestasi olahraga (Eko Haris, 2012: 146).

Makanan bagi pekerja berat ibarat bensin untuk kendaraan bermotor. Pekerja harus memperhatikan asupan gizi yang masuk dalam tubuh. Pekerja makan bukan sekedar memperoleh rasa kenyang tetapi harus memperhatikan nilai gizi dalam makanan. Perilaku 
sehat dapat dilakukan dengan cara mengonsumsi sayuran, buah-buahan dan olahraga teratur yang akan berhubungan dengan kebiasaan, gaya hidup yang sehat, dan mengontrol tingkat stres (Wynn Gillan, 2005: 58).

Selain status gizi, tingkat kebugaran pekerja juga harus menjadi perhatian. Kebugaran yang baik sudah menjadi modal awal untuk maju dalam melakukan aktivitas yang berhubungan dengan pekerjaan atau kegiatan lain, yang membuat aktivitas dapat dilakukan berulang-ulang dalam waktu yang relatif lama tanpa menimbulkan kelelahan fisik yang berarti (Djoko Pekik I, 2000:9). Status gizi sangat berpengaruh terhadap tingkat kebugaran seseorang.

Status gizi sangat berpengaruh terhadap tingkat kebugaran seseorang. Pemeliharaan dan perbaikan sel-sel otot yang rusak dapat berjalan dengan baik jika seseorang mempunyai asupan gizi yang baik. Komponen kebugaran jasmani yang berhubungan dengan kesehatan terdiri atas daya tahan jantung-paru, kekuatan otot, kelentukan, dan komposisi tubuh. Kebugaran jasmani yang baik akan sangat berpengaruh pada produktivitas kerja. Pekerja memerlukan tingkat kebugaran agar tidak mudah kelelahan dan tidak mudah terkena cedera yang timbul akibat kelelahan fisik.

Meningkatkan status kebugaran salah satunya dapat dilakukan dengan cara berolahraga secara teratur. Saat bekerja pekerja harus memiliki kondisi tubuh yang bugar agar dapat meningkatkan produktivitas kerja. Peningkatan tingkat kebugaran dapat memengaruhi produktivtas karyawan, kepuasan kerja, dan kehadiran karyawan (Matthew, 2003: 31).

Dari hasil observasi dan wawancara langsung yang dilakukan oleh peneliti kepada pemilik dan pekerja pembuat buis beton banyak yang mengeluh bahwa hasil produk yang dapat dihasilkan jumlahnya tidak menentu. Kondisi pekerja tidak selalu dalam kondisi prima. Hal tersebut dipengaruhi oleh banyak faktor, di antaranya yaitu status kebugaran dan status gizi pekerja yang masih kurang. Dalam pembuatan buis beton pekerja lebih banyak menggunakan fisik. Oleh karena itu pekerja dituntut untuk memiliki kondisi fisik yang baik. Kondisi fisik yang baik dapat diperoleh dengan cara makan makanan yang bergizi dan aktivitas fisik/olahraga yang teratur.

\section{KAJIAN PUSTAKA}

\section{Kebugaran Jasmani}

Kebugaran yang dimiliki seorang akan mempunyai dampak positif terhadap kinerja seseorang dan juga akan memberikan dukungan terhadap produktivitas bekerja dan belajar. Seseorang yang memiliki derajat kebugaran jasmani yang baik akan memiliki kemampuan yang baik dalam melaksanakan tugas-tugas yang berhubungan dengan fisik yang diberikan 
kepadanya. Selain itu, ia akan mengalami kelelahan yang tidak berarti setelah melakukan tugasnya.

Menurut Suharjana (2013: 3), Kebugaran jasmani dapat diartikan sebagai kesanggupan seseorang untuk menjalankan hidup sehari-hari tanpa menimbulkan kelelahan yang berlebihan dan masih memiliki kemampuan untuk mengisi pekerjaan ringan lainnya. Menurut Joko Pekik I (2006: 2), kebugaran adalah kemampuan seseorang melakukan kerja sehari-hari secara efisien tanpa timbul kelelahan yang berlebihan sehingga masih dapat menikmati waktu luangnya. Seseorang yang memiliki tingkat kebugaran yang baik tidak akan mengalami kelelahan yang berarti setelah melakukan pekerjaan.

\section{Komponen-Komponen Kebugaran Jasmani}

Menurut DjokoPekik I (2004: 4) kebugaran yang berhubungan dengan kesehatan memiliki empat komponen dasar, yaitu:

1. Daya tahan paru-jantung, yakni kemampuan paru-jantung menyuplai oksigen untuk kerja otot dalam jangka waktu lama.

2. Kekuatan dan daya tahan otot

Kekuatan otot adalah kemampuan otot melawan beban dalam satu usaha. Daya tahan otot adalah kemampuan otot melakukan serangkaian kerja dalam waktu yang lama.

3. Kelentukan adalah kemampuan persendian bergerak secara leluasa.

4. Komposisi tubuh adalah perbandingan berat tubuh berupa lemak dengan berat tubuh tanpa lemak yang dinyatakan persentase dalam lemak tubuh.

Menurut Suharjana (2013: 7) kebugaran yang berhubungan dengan keterampilan terdiri atas komponen-komponen sebagai berikut:

1. Kecepatan adalah kemampuan untuk menempuh jarak tertentu dalam waktu yang sesingkatsingkatnya.

2. Daya ledak adalah kombinasi antara kekuatan dan kecepatan yang merupakan dasar dari setiap melakukan aktivitas. Daya ledak adalah kemampuan kerja otot yang dalam satuan waktu. Daya ledak merupakan hasil kali antara kekuatan dan kecepatan. Daya ledak penggunaanya terbagi menjadi dua golongan, yaitu: (a) siklik adalah penggunaan power yang dilakukan secara berulang-ulang dan sama. Contoh lari, bersepeda, mendayung, (b) asiklik adalah penggunaan power yang dilakukan dalam satu gerakan saja. Contoh meloncat, melempar.

3. Keseimbangan. Keseimbangan tubuh adalah kemampuan untuk mempertahankan sikap tubuh yang tepat saat melakukan gerakan atau pada saat berdiri. 
4. Kelincahan. Kelincahan adalah kemampuan bergerak memindahkan tubuh untuk mengubah arah dengan cepat dan tepat.

5. Koordinasi. Koordinasi adalah perpaduan beberapa unsur gerak dengan melibatkan gerak tangan, kaki, dan mata secara serempak untuk hasil gerak yang maksimal dan efisien.

\section{Status Gizi}

Suharno (2006: 15) menyatakan bahwa status gizi adalah keadaan yang disebabkan oleh konsumsi, penyerapan, dan penggunaan makanan. Sususnan makanan yang memenuhi gizi tubuh pada umumnya menciptakan status gizi yang baik. Status gizi adalah keadaan yang diakibatkan oleh konsumsi, penyerapan, dan penggunaan makanan. Susunan makanan yang memenuhi kebutuhan gizi tubuh pada umumnya menciptakan status gizi yang memuaskan (Suhardjo, 2006: 15).

Menurut Almatsier (2004) yang dikutip oleh Ari Istiany (2013: 5) status gizi juga dinyatakan sebagai keadaan tubuh yang merupakan akibat dari konsumsi makanan dan penggunaan zat gizi dengan empat klasifikasi, yaitu status gizi buruk, kurang baik, baik, dan lebih. Fungsi utama makanan adalah penyedia energi bagi aktivitas sel-sel tubuh. Zat gizi yang merupakan penyedia energi bagi tubuh adalah karbohidrat, lemak, dan protein.

\section{Penilaian Status Gizi}

Menurut Djoko Pekik I (2006: 3) penilaian status gizi dapat dilakukan dengan berbagai cara yang meliputi:

1. Pemeriksaan Langsung

a. Antropometri, pengukuran tinggi badan, berat badan, tebal lemak tubuh.

b. Biokimia, pemeriksaan laboratorium (biokimia) terutama untuk mengetahui keadaan hemoglobin, feritin, glukosa, dan kolesterol.

c. Klinis, untuk mengetahui keadaan kekurangan zat gizi tertentu.

2. Pemeriksaan Tidak Langsung

a. Survei konsumsi, dilakukan dengan wawancara kebiasaan makan dan perhitungan konsumsi.

b. Statistik vital, dilakukan dengan menganalisis dan kesehatan, seperti angka kematian, kesekitan, akibat hal yang berhubungan dengan status gizi.

c. Faktor ekologi, didasarkan atas ketersediaan makanan yang dipengaruhi oleh faktor ekologi (iklim, tanah, irigasi, dll).

Hal mendasar yang perlu diingat bahwa setiap metode penilaian status gizi mempunyai kelebihan dan kelemahan. Dari berbagai cara penilaian di atas, yang paling sering dilakukan adalah dengan cara pengukuran antropometri, karena lebih menghemat waktu dan biaya. 


\section{Produktivitas Kerja}

Menurut Bambang Kusriyanto yang dikutip oleh Nur Hidayat (2004: 11), Produktivitas adalah suatu sistem dimana, dengan motivasi merupakan salah satu sarana untuk peningkatan. Manajemen personalia sebagai titik tolak yang membidangi ketenagakerjaan. Produktivitas adalah perbandingan antara hasil yang dicapai dengan keseluruhan sumber daya yang dipergunakan (Rini Retno, 2004: 25).

Secara singkat produktivitas dapat diartikan sebagai perbandingan jumlah keluar (output) tertentu dengan jumlah masukan (input) tertentu untuk jangka waktu tertentu. Dalam upaya meningkatkan produktivitas kerja karyawan di suatu perusahaan perlu memperhatikan faktorfaktor yang memengaruhi produktivitas kerja karyawan tersebut. Banyak faktor yang memengaruhi produktivitas karyawan baik yang berhubungan dengan tenaga kerja itu sendiri maupun faktor yang berhubungan dengan lingkungan perusahaan dan kebijakan pemerintah secara keseluruhan.

\section{Macam-Macam Zat Gizi dan Manfaatnya}

Menurut Djoko Pekik I (1997: 5) yang dikuti oleh Syahban Junen (2005: 12) karakter dan manfaat gizi adalah sebagai berikut:

1. Karbohidrat

Karbohidrat adalah suatu senyawa sumber energi utama bagi tubuh manusia sebanyak $80 \%$ kalori yang didapat tubuh berasal dari karbohidrat.

Karbohidrat mempunyai tiga kegunaan, yaitu:
a. Sumber energi utama yang diperlukan untuk bergerak.
b. Pembentuk cadangan sumber energi dalam bentuk lemak.
c. Memberikan rasa kenyang.

2. Lemak

Lemak adalah garam yang terjadi dari penyatuan asam lemak dengan alkohol organik yang disebut gliseril atau gliserin. Dalam tubuh lemak bermanfaat sebagai berikut:
a. Sebagai sumber energi.
b. Melarutkan vitamin sehingga dapat diserap oleh usus.
c. Sebagai bantuan alat tubuh.
d. Memberikan garis tubuh.
e. Memperlama rasa kenyang.

3. Protein

Protein merupakan bahan utama pembentuk sel tumbuhan, hewan, dan manusia. Oleh karena itu, protein disebut zat pembangun. Manfaat protein bagi tubuh manusia, yakni 
a. Membangun sel tubuh.

b. Mengganti sel tubuh.

c. Membentuk protein darah, untuk mempertahankan stabilitas tekanan osmose struktur darah.

d. Membuat air susu, enzim, dan hormon.

e. Menjaga keseimbangan asam basa cairan tubuh, untuk mengikat kelebihan asam atau basa.

f. Pemberi kalori dalam keadaan memaksa

4. Vitamin

Vitamin adalah senyawa organik yang diperlukan oleh tubuh dalam jumlah sedikit untuk mengatur fungsi tubuh seperti pertumbuhan normal, memelihara kesehatan, dan reproduksi. Vitamin tidak dapat dihasilkan oleh tubuh, sehingga harus diperoleh dari bahan makanan. Vitamin bekerja sebagai biokatalisator, yaitu berperan untuk memperlancar reaksi dalam tubuh.

5. Mineral

Mineral adalah zat organik yang diperlukan oleh tubuh dalam jumlah kecil untuk membantu reaksi fungsional tubuh, misalnya untuk memelihara keteraturan metabolisme. Kurang lebih $4 \%$ tubuh manusia terdiri atas mineral.

6. Air

Air merupakan komponen terbesar dari struktur tubuh manusia kurang lebih $60 \%$ berat badan orang dewasa berupa air, di dalam tubuh air berfungsi untuk:

a. Media transportasi zat gizi, membuang sisa metabolisme.

b. Mengatur temperatur tubuh.

c. Mempertahankan keseimbangan volume darah.

\section{Faktor yang Memengaruhi Produktivitas Kerja}

John Suprihanto, (1992: 19) yang dikutip oleh Rini Retno (2004: 25) menyatakan faktorfaktor yang memengaruhi produktivitas, yaitu pendidikan, motivasi, disiplin kerja, keterampilan, sikap dan etika kerja, tingkat penghasilan, lingkungan dan iklim kerja, teknologi, sarana produksi, jaminan sosial, manajeman, dan kesempatan berprestasi.

Menurut Rini Retno ( 2004: 29) produktivitas tenaga kerja dapat ditingkatkan, maka hal yang harus diperhatikan antara lain:

1. Kualitas dan kemampuan fisik tenaga kerja.

2. Sarana pendukung yang meliputi antara lain: 
a. Lingkungan kerja antara lain berupa sarana, peralatan produksi, teknologi, dan keadaan lingkungan kerja.

b. Pemenuhan kesejahteraan dan kebutuhan tenega kerja antara lain berupa jaminan sosial, tunjangan, sistem pengupahan, pemberian insentif yang tepat, dan pemenuhan kebutuhan yang lain.

c. Kemampuan manajemen dalam menggunakan sumber daya yang ada secara maksimal dan menciptakan sistem kerja yang baik.

\section{Cara Pembuatan Bius Beton}

Buis beton adalah bahan bangunan yang biasanya dipakai untuk membuat sumur, goronggorong, resapan air, dan lain-lain. Buis beton terbuat dari campuran semen, pasir, dan batubatu kecil. Saat ini penggunaan buis beton dalam pembangunan sangat penting karena dapat memudahkan pekerja dalam membuat sumur, gorong-gorong, resapan iar, dan lain-lain. Cara pembuatan buis beton yaitu:

1. Menyiapkan cetakan buis beton dengan diameter yang diinginkan. Pada tahap ini pekerja membutuhkan kekuatan otot lengan dan otot tungkai untuk mengangkat dan memindahkan cetakan buis beton.

2. Melumuri bagian dalam cetakan dengan pelumas atau oli bekas agar saat melepaskan cetakan lebih mudah.

3. Memberi alas pada cetakan supaya buis beton yang dibuat tidak menempel pada tanah

4. Mencampur bahan yang digunakan untuk mebuat buis beton yang terdiri atas pasir dan semen.

5. Mengaduk campuran pasir dan semen hingga merata. Pada tahap ini pekerja membutuhkan kekuatan otot lengan untuk mengaduk, karena cara mengaduk masih dilakukan secara manual dengan tangan. Karena posisi pekerja saat mengaduk berdiri dan sedikit membungkuk, pekaeja juga membutuhkan kekuatan otot tungkai yang baik. Selain juga kelentukan tubuh yang baik.

6. Memasukkan campuran yang sudah jadi ke dalam cetakan sedikit demi sedikit dan dipadatkan dengan cara ditumbuk. Tahap ini merupakan hal yang paling penting dalam pembuatan buis beton karena jika tidak teliti, hasilnya menjadi kurang baik. Pekerja menumbuk dengan cara manual manggunakan tangan. Oleh sebab itu, kekuatan otot lengan pekerja harus baik. Posisi tubuh pekerja pada saat menumbuk berdiri. Selain itu pekerja juga membutuhkan kelentukan yang baik, karena posisi tubuh pekerja selalu berubah-ubah saat mengambil campuran dan menumbuk. Cetakan harus diisi sampai penuh. 
7. Mendiamkan cetakan yang sudah penuh selama kurang lebih 20 menit.

8. Melepas cetakan buis beton yang sudah jadi dengan hati-hati agar tidak merusak buis beton yang sudah dicetak.

\section{METODE PENELITIAN}

Penelitian ini merupakan penelitian observasional cross sectional. Metode pengambilan data yang digunakan adalah survei dengan teknik tes dan pengukuran. Metode survei adalah penyelidikan yang diadakan untuk memperoleh fakta-fakta dari gejala-gejala yang ada dan mencari kekurangan-kekurangan secara faktual. Penelitian ini bertujuan untuk mengetahui hubungan status gizi dan status kebugaran dengan produktivitas kerja pekerja pembuat buis beton di Dusun Blawong I, Trimulyo, Jetis, Bantul. Populasi yang digunakan dalam penelitian ini adalah seluruh pekerja pembuat buis beton yang berada di Dusun Blawong I, Trimulyo, Jetis, Bantul dan yang menjadi sampel pekerja buis beton berjumlah limas belas orang. Teknik sampling yang digunakan yaitu purposive sampling dengan memperhatikan usia antara 25-40 tahun dan lama bekerja sebagai pembuat buis beton minimal 1 tahun.

\section{HASIL PENELITIAN}

Berdasarkan usia, mayoritas subjek penelitian ini berusia 31-35 tahun sebanyak 7 orang (46,7 \%), sedangkan subjek yang berusia 25-30 tahun sebanyak 5 orang $(33,3 \%)$ dan subjek yang berusia 36-40 tahun sebanyak 3 orang (20\%). Berdasarkan tinggi badan, mayoritas subjek sebanyak 9 orang $(60 \%)$ orang memiliki tinggi badan antara $161 \mathrm{~cm}-165 \mathrm{~cm}, 4$ orang $(26,7$ \%) subjek memiliki tinggi badan antara $155 \mathrm{~cm}-160 \mathrm{~cm}$, dan sebanyak 2 orang (13,3\%) subjek penelitian memiliki tinggi badan antara $166 \mathrm{~cm}-170 \mathrm{~cm}$. Berdasarkan berat badan, mayoritas subjek penelitian sebanyak 9 orang (60\%) orang memiliki berat badan antara $56 \mathrm{~kg}-60 \mathrm{~kg}$, sebanyak 3 orang (20\%) subjek penelitian memiliki berat badan antara $50 \mathrm{~kg}-55 \mathrm{~kg}$, dan sebanyak 3 orang (20\%) subjek penelitian memiliki berat badan antara $61 \mathrm{~kg}-65 \mathrm{~kg}$.

Analisis deskriptif dalam penelitian ini meliputi analisis satistik deskriptif meliputi IMT, daya tahan jantung paru, kekuatan otot tungkai, kekuatan otot lengan, kelentukan, persentase lemak, produktivitas kerja. Adapun uraiannya disajikan sebagai berikut.

1. Indeks Masa Tubuh (IMT)

Pengkategorian IMT terdiri atas lima kategori, yaitu sangat kurus, kurus, normal, gemuk, dan obesitas. Berikut disajikan distribusi frekuensi data IMT subjek penelitian (Depkes, RI). Dari 15 orang subjek penelitian, seluruh (100\%) subjek penelitian berada 
pada kategori IMT normal. Dengan demikian dapat dikatakan bahwa kategori IMT pembuat buis beton di Dusun Blawong termasuk pada kategori normal.

2. Daya Tahan jantung Paru

Penilaian daya tahan jantung-paru subjek penelitian berdasarkan pada harvard step test. Dari keseluruhan subjek penelitian, mayoritas daya tahan jantung-paru termasuk pada kategori baik dengan jumlah subjek sebanyak 12 orang, dan 3 orang kategori kebugaranya adalah rata-rata.

3. Kekuatan Otot Tungkai

Penilaian kekuatan otot tungkai berdasarkan data hasil tes menggunakan leg dynamometer. Pengkategorian kekuatan otot tungkai terdiri atas lima kategori, yaitu sangat baik, baik, sedang, kurang, dan kurang sekali (Vivian H, 1998). Dari lima belas orang subjek penelitian, mayoritas subjek penelitian kekuatan otot tungkainya termasuk baik dengan jumlah subjek sebanyak 6 orang (40\%), 4 orang $(26,7 \%)$ dalam ketegori sangat baik, sedangkan 5 orang (33,3 \%) termasuk pada kategori sedang. Dengan demikian dapat dikatakan bahwa kategori kekuatan otot tungkai pembuat buis beton di Dusun Blawong termasuk pada kategori baik.

4. Kekuatan Otot Lengan

Penilaian kekuatan otot lengan berdasarkan data hasil tes expanding dynamometer. Pengkategorian kekuatan otot lengan terdiri atas lima kategori, yaitu sangat baik, baik, sedang, kurang, dan kurang sekali. dari 15 orang subjek penelitian, mayoritas sebanyak 10 orang $(66,7 \%)$ subjek penelitian kekuatan otot lengannya termasuk dalam kategori baik, sedangkan 5 orang $(33,3 \%)$ subjek penelitian termasuk sangat baik kekutan otot lengannya. Dengan demikian dapat dikatakan bahwa kategori kekuatan otot lengan pembuat buis beton di Dusun Blawong termasuk pada kategori baik.

5. Kelentukan

Penilaian kelentukan berdasarkan pada data hasil tes sit and reach. Pengkategorian kelentukan terdiri atas lima kategori, yaitu sangat baik, baik, sedang, kurang, dan kurang sekali. keseluruhan subjek penelitian sebanyak 15 orang (100\%) subjek penelitian termasuk dalam kategori sangat baik kelentukkannya. Dengan demikian dapat dikatakan bahwa kelentukkan pembuat buis beton di Dusun Blawong termasuk pada kategori sangat baik.

6. Persentase Lemak

Penilaian persentase lemak berdasarkan data hasil tes skinfold pada empat bagian tubuh yaitu triceps, biceps, subscapula, dan suprailliaca. Pengkategorian persentase lemak 
terdiri atas lima kategori, yaitu lemak sangat rendah, lemak rendah, lemak rata-rata, lemak di atas normal, dan lemak sangat tinggi. Dari 15 orang subjek penelitian, mayoritas sebanyak 14 orang (93,3 \%) subjek penelitian persentase lemaknya termasuk dalam kategori rendah, dan 1 orang $(6,7 \%)$ subjek penelitian termasuk dalam kategori lemak ratarata. Dengan demikian dapat dikatakan bahwa subjek penelitian persentase lemaknya sangat rendah.

7. Produktivitas Kerja

Penilaian produktivitas kerja berdasarkan produktivitas subjek penelitian dalam membuat buis beton selama tujuh hari (satu minggu). Pengkategorian produktivitas kerja terdiri atas lima kategori, yaitu sangat tinggi, tinggi, sedang, rendah, dan sangat rendah. Dari 15 orang subjek penelitian, mayoritas sebanyak 5 orang $(33,3 \%)$ subjek penelitian termasuk dalam kategori sedang produktivitas kerjanya, 1 orang $(6,7 \%)$ subjek penelitian termasuk dalam kategori lemak sangat tinggi, 4 orang (26,7 \%) subjek penelitian tinggi produktivitas kerjanya, 4 orang $(26,7 \%)$ rendah prodkuktivitas kerjanya, dan 1 orang $(6,7$ $\%)$ produktivitasnya rendah. Dengan demikian dapat dikatakan bahwa produktivitas kerja subjek latihan adalah sedang.

\section{PEMBAHASAN}

Penelitian ini bertujuan untuk mengetahui hubungan status kebugaran dan status gizi dengan produktivitas kerja pekerja pembuat buis beton di Dusun Blawong I, Trimulyo, Jetis, Bantul. Status kebugaran dalam penelitian ini dilihat dan diukur dari komponen-komponen kebugaran jasmani yang berhubungan dengan kesehatan yaitu daya tahan jantung paru, kekuatan otot,kelentukan, dan persentase lemak. Status gizi dilihat dan diukur dengan IMT. Hasil penelitian status kebugaran jasmani pekerja yang dilihat dari komponen-komponen kebugaran jasmani yang berhubungan dengan kesehatan menunjukkan bahwa dari hasil analisis statistik korelasi mengunakan product moment (pearson corelation) menunjukkan hasil korelasi sebesar $\mathrm{p}<0,05$ dengan arah positif yang berarti terdapat hubungan yang signifikan antara daya tahan jantung paru dan produktivitas kerja. Korelasi ini menggambarkan bahwa semakin baik daya tahan paru jantung pekerja semakin tinggi produktivitas kerja pekerja tersebut. seorang yang mempunyai daya tahan jantung-paru yang baik, maka kemampuan sistem sirkulasi dan kerja jantung akan berjalan lancar sehingga dapat menyuplai oksigen dengan baik. Oleh karena itu, seorang pekerja tidak akan cepat lelah saat bekerja.

Hasil analisis korelasi menggunakan product moment (pearson corelation) antara kekuatan otot lengan dan kekuatan otot tungkai menunjukkan $\mathrm{p}<0,05$ dengan arah positif $(+)$ 
yang berarti terdapat hubungan yang signifikan kekuatan otot lengan dan kekuatan otot tungkai dengan produktivitas kerja. Korelasi ini menggambarkan semakin tinggi kekuatan otot lengan dan kekuatan tungkai yang dimiliki pekerja, produktivitas kerja juga akan semakin tinggi. Kekuatan otot tungkai sangat diperlukan oleh seorang pekerja buis beton. Pada saat proses mengaduk campuran bahan posisi pekerja akan sedikit membungkuk, selain itu posisi pekerja pada saat mencetak buis beton pekerja akan berdiri sedangkan otot lengan diperlukan pada saat proses pemadatan campuran di dalam cetakan.

Hasil analisis korelasi menggunakan product moment (pearson corelation) antara kelentukan produktivitas kerja menunjukkan hasil korelasi sebesar $\mathrm{p}<0,05$ dengan arah positif $(+)$ yang berarti terdapat hubungan yang signifikan kelentukan dengan produktivitas kerja. Pada proses pembuatan buis beton kelentukan dibutuhkan pada saat pekerja mengambil adonan lalu memasukkan adonan ke dalam cetakan. Posisi tubuh pada saat mengambil adonan dengan membungkuk, kemudian posisi pada saat memasukkan adonan kedalam cetakan harus berdiri. Jika pekerja memiliki kelentukan yang baik, pekerja tidak akan mudah cedera.

Hasil analisis korelasi menggunakan product moment (pearson corelation) antara persentase lemak dan produktivitas kerja menunjukkan hasil korelasi $\mathrm{p}<0,05$ dengan arah negatif yang berarti terdapat hubungan yang signifikan antara persentase lemak dan produktivitas kerja. Korelasi ini menggambarkan semakin tinggi persetase lemak yang dimiliki pekerja produktivitas kerja akan semakin menurun. Persentase lemak yang terlalu banyak di dalam tubuh akan menyebabkan seseorang obesitas. Seseorang yang obesitas akan terbatas atau mengalami kesusahan dalam melakukan aktivitas atau gerak. Hal ini akan memengaruhi produktivitas seorang pekerja.

Dari analisis korelasi menggunakan product moment( pearson corelation) pada status kebugaran jasmani yang diukur melalui komponen-komponen kebugaran jasmani yang berhubungan dengan kesehatan menunjukkan bahwa semua komponen kebugaran berhubungan dengan tingkat produktivitas kerja. Status kebugaran pekerja diukur melalui kompnen-komponen kebugaran jasmani yang berhubungan dengan kesehatan karena seorang pekerja pembuat buis beton dalam proses pembuatan memerlukan daya tahan jantung-paru, kekuatan otot lengan dan otot tungkai, kelentukan, dan persentase lemak.

Hasil analisis korelasi menggunakan product moment (pearson corelation) menunjukkan hasil korelasi IMT dengan produktivitas kerja $\mathrm{p}<0,05$ dengan arah positif yang berarti terdapat hubungan yang signifikan IMT dengan produktivitas kerja. Korelasi ini menggambarkan bahwa semakin baik IMT yang dimiliki pekerja, produktivitas kerja juga akan semakin tinggi. 
Hasil uji regresi ganda menunjukkan bahwa nilai p (sig) sebesar 0,004 dan nilai R Square sebesar 0,863. Hal tersebut berarti IMT, daya tahan jantung-paru, kekuatan otot tungkai, kekuatan otot lengan, kelentukan, dan persentase lemak tubuh secara bersama (simultan) berhubungan dengan produktivitas kerja dengan besar persentase sumbangan sebesar 86,3\%. Selain itu, hasil koefisien korelasi regresi ganda menunjukkan bahwa nilai b terbesar atau tertinggi adalah kekuatan otot lengan, sehingga dapat disumpulkan bahwa kekuatan otot lengan memberikan sumbangan yang lebih besar daripada varibel lainnya terhadap produktivitas kerja.

\section{KESIMPULAN}

Status kebugaran jasmani pekerja pembuat buis beton di Dusun Blawong I yang dilihat dari komponen-komponen kebugaran jasmani yang berhubungan dengan kesehatan menunjukkan keadaan pekerja mayoritas dalam status baik. Status gizi pekerja pembuat buis beton di Dusun Blawong I menunjukan semua pekerja dalam status normal. Di sisi lain, produktivitas kerja pekerja pembuat buis beton di Dusun Blawong I mayoritas dalam kategori sedang. Status kebugaran jasmani pekerja pembuat buis beton di Dusun Blawong I yang dilihat dan diukur dari komponen-komponen kebugaran jasmani yang berhubungan dengan kesehatan semua menunjukkan adanya hubungan yang signifikan dengan produktivitas kerja pekerja pembuat buis beton di Dusun Blawong I. Terdapat hubungan yang signifikan status gizi dengan produktivitas kerja pekerja pembuat buis beton di Dusun Blawong I. IMT, daya tahan jantungparu, kekuatan otot tungkai, kekuatan otot lengan, kelentukan, dan persentase lemak secara bersama (simultan) memberikan sumbangan pada produktivitas kerja. Kekuatan otot lengan memberikan sumbangan paling besar terhadap produktivitas kerja.

\section{DAFTAR PUSTAKA}

Bambang Tri Cahyono. (1996). Manajemen Sumber Daya Manusia. Jakarta: Badan Penerbit IPWI.

Djoko Pekik I. (2000). Panduan Latihan Kebugaran Jasmani. Yogyakarta: Lukman Offset.

Djoko Pekik I. (2004). Bugar dan Sehat dengan Olahraga. Yogyakarta: CV Andi Off Set.

Gillan Wynn, dkk. (2005). Correlations among Stress, Pysical Activity and Nutrition: School Employee Health Behavior. Journal of Research, (1): 55-60.

I Nyoman Supariasa. (2002). Penilaian Status Gizi. Jakarta: Kedokteran EGC. 
Ismaryanti. (2011). Tes dan Pengukuran Olahraga. Surakarta: Universitas Sebelas Maret.

Ngatman. (2001). Tes dan Pengukuran. Yogyakarta: FIK UNY.

Nur Hidayat.(2004). Hubungan Status Kebugaran Jasmani dengan Produktivitas Kerja Karyawan AGIOS CRAFT. Skripsi. FIK UNY.

Marsetyo dan Kartasapoetra. (2008). Ilmu Gizi (Korelasi Gizi Kesehatan dan Produktivitas Kerja). Jakarta: Rineka Cipta.

Matthew \& Chad Harris.(2003). The Relationship Between Fitness Levels and Empoyee's Perceived Productivity, Job Statisfaction, and Absenteeism. Official Journal of American Society Physiology, 6 (1), 24-32.

Muchdarsyah Sinangun. (2003). Produktivitas Apa dan Bagaimana. Jakarta: Bumi Aksara.

Suhardjo. (2006). Pangan, Gizi, dan Pertanian. Jakarta: Universitas Indonesia Press.

Suharjana. (2013). Kebugaran Jasmani. Yogyakarta: Jogja Global Media.

Sunita Almatsier. (2003). Prinsi-Prinsip Ilmu Gizi. Jakarta: PT. Gramedia Pustaka Utama.

Wahyu Nurhidayati. (2004). Hubungan Antara Status Gizi dan Tingkat Kebugaran Jasmani Siswa Kelas V SD Muhammadiyah 1 Ngupasan. Skripsi. FIK UNY. 